\title{
E-BANKING SERVICES IN PUBLIC AND PRIVATE SECTOR BANKS IN INDIA- WITH SPECIAL REFERENCE TO SBI AND ICICI BANK
}

\author{
Dr. P.Chengalrayulu ${ }^{1}$, Dr. A.Nagaraju ${ }^{2}$ and Prof. K.Ramakrishnaiah ${ }^{3}$ \\ ${ }^{1}$ Department of Commerce, S.V.U College of CM\&CS, Sri Venkateswara University, Tirupati-517502, \\ A.P. \\ ${ }^{2}$ Lecturer in Commerce, Department of Commerce, Government College for Men (A), Kadapa-516002. \\ ${ }^{3}$ Retired Professor\& Senior Research Fellow (ICSSR), Department of Commerce, S.V.U College of \\ CM\&CS, Sri Venkateswara University, Tirupati-517502, A.P.
}

DOI: 10.46609/IJSSER.2020.v05i09.015 URL: https://doi.org/10.46609/IJSSER.2020.v05i09.015

\begin{abstract}
Now-a-days e-banking is the popular technology used by banks. E-banking is the outcome of technological innovations and competition. In fact, banks have been using electronic and telecommunication networks for delivering a wide range of value added products and services. The specific objectives of the present study are to analyze the various internet banking facilities offered by the selected public and private banks to its customers and to study the benefits that is provided to the individual customers under internet banking. The primary data has been collected from the customers of SBI and ICICI Bank for the year 2019-20. A total of 120 customers from each of the banks viz., SBI and ICICI Bank were selected from the list obtained from the said banks by adopting simple random sampling procedure (systematic sampling). Under simple random sampling procedure (systematic sampling procedure) at first the first name of the customer in the list given is selected as number one and after words every $10^{\text {th }}$ name of the customer was selected till the number reaches to 120. This paper suggested that the thumb impression is used as a PIN code or Password for Internet Banking to avoid hacker's money theft in technological banking. It is concluded that the popularity of e-banking is increasing and banks are adopting the latest technology, they are prone towards cyber crimes and greater is the potential for reputational risks also, therefore, there is a need to have sound security controls and strong cyber laws in India.
\end{abstract}

Keywords: e-banking, competition, public sector banks and private sector banks 
International Journal of Social Science and Economic Research

ISSN: 2455-8834

Volume:05, Issue:09 "September 2020"

\section{INTRODUCTION}

Banks in India need to be admired on the enclosure of technology in a large way in their daytoday operations. The last two decade has seen many constructive developments in the Indian Banking Sector. Nowadays e-banking is the popular technology used by banks. E-banking is the outcome of technological innovations and competition. In fact, banks have been using electronic and telecommunication networks for delivering a wide range of value added products and services. As a part of their e-banking initiatives banks offered the following new delivery channels to customer's Automated Teller Machines (ATM)/ Cash Dispensers (CD), Phone banking, Internet banking and Mobile banking. Banks used e-banking as mechanism to fight fierce competition that existed in the market and also to retain the customers base they had customer's response to e-banking was enthusiastic and followed predicted path of Technology Adoption Life Cycle models. E- Banking is about using the infrastructure for digital age to create opportunities, both local \& global. IT enables the dramatic lowering of transaction cost and the creation of new types of banking opportunities that address the barriers of time and distance. Banking opportunities are local, global and immediate in e-banking and development of the financial institutions. Financial institutions have begun to realize that though the internet is simply a delivery channel it is an extremely powerful one. Therefore, financial institutions are investing in electronic customer relationship management (eCRM) solutions that span across all the channels with the goal of strengthening the customer loyalty and increasing fee based transactions.

\section{REVIEW OF LITERATURE}

Safeena, Rehmath (2010) have emphasized that the customer perspective regarding adaptation of internet banking. The main objective of this study is to analysis the impact of perceived usefulness and ease of use along with consumer consciousness on internet banking and perceived uncertainty on the adaptation of e- banking by the consumers. The conclusion of the study is that there are so many factors which force the customer to adopt online banking and these factors are easy to use and less time consuming system.

Krishnamoorthy, V. and R. Srinivasan(2013) concluded that it is so difficult for the bank to retain their existing customer. Bank need to work out on some important issues for their long lasting survival, like make some new innovation in the product as per the needs and wants of the customer or they need to develop strong trust and relationship among the existing customer.

Thanga Glara. K. \& Eugine Franco. C. (2017) in their paper entitled "A Comparative Study on Satisfaction of Customers of Public Sector and Private Sector Banks towards E-Banking In Tirunelveli District" have argued that to find out the factors influencing in the adoption of E- 


\section{International Journal of Social Science and Economic Research}

ISSN: $2455-8834$

Volume:05, Issue:09 "September 2020"

banking provided by public and private sector banks, identify the level of satisfaction of customers of public and private sector banks towards their usage of E-banking. Convenience sampling method have adopted for this study. The primary data were collected from questionnaire method. From the analysis, it is found that with regard to satisfaction in ATM services, the customers of both sectors of banks are equally satisfied. Also the customers are satisfied with the e-banking services provided by private sector banks. It is suggested that ease of use is the major factor to induce the customers to adopt e-banking. Therefore banks should maintain its applications more user friendly and up to date. ATMs receive the higher attraction among the e-banking channels.

Pinki Insan and Sapna Kumari (2015) in their paper entitled "Customer's Perception towards Internet Banking: A Study of Sirsa City" tried to identify the customers' perception towards Internet banking and to analyze their satisfaction level about Internet banking. The paper presented the analysis of 100 Internet banking customers having saving and current accounts in Sirsa City. Percentages and frequencies had been applied for analysis to explore the results of the survey. Charts had also been prepared to depict the data. It was found that majority of the customers preferred to open saving account in PNB. People were also aware of and were satisfied with the internet banking services provided by their banks. The most important factor behind using internet banking was that it was more convenient. This study also suggested that the internet banking services can also be improved by dealing with the customers with polite behaviour and making personal contacts and by providing some extra benefits to the users of this facility so that they won't switch to any other bank.

\section{OBJECTIVE OF THE PRESENT STUDY}

The specific objectives of the present study are to analyze the various internet banking facilities offered by the selected public and private sector banks to its customers and to study the benefits that is provided to the individual customers under internet banking.

\section{HYPOTHESES}

$>$ There is no significant association between the gender classification of sample respondent customers of SBI and ICICI Bank.

$>$ There is no significant association between the educational qualifications of sample respondent customers of SBI and ICICI Bank.

$>$ There is no significant association between the marital status of sample respondent customers of SBI and ICICI Bank.

$>$ There is no significant association between time period usage of e-banking services provided by the SBI and ICICI Bank and 
International Journal of Social Science and Economic Research

ISSN: 2455-8834

Volume:05, Issue:09 "September 2020"

There is no significant association between awareness of various e-banking services among sample respondent customers of SBI and ICICI Bank

\section{RESEARCH METHODOLOGY}

The study is diagnostic and exploratory in nature and made use of both primary and secondary data. The primary data have been collected through a well structured, pretested questionnaire. The universe of the present study constitutes public sector banks (27), private sector banks (20), foreign banks in India (44) and Regional Rural Banks (56). The Regional Rural Banks and foreign banks have been excluded from the scope of the present study. The public sector and private sector banks have been considered for the present study. So, the study has picked up one out of 27 public sector banks and one out of 20 private sector banks. This sample falls under the technique of convenience sampling. Further, a total of 120 customers from each of the banks viz., SBI and ICICI Bank were selected from the list obtained from the said banks by adopting simple random sampling procedure (systematic sampling). Under simple random sampling procedure (systematic sampling procedure) at first the first name of the customer in the list given is selected as number one and after words every $10^{\text {th }}$ name of the customer was selected till the number reaches to 120. A questionnaire was designed and deployed to each of the 120 customers selected from each of the Bank selected for eliciting information on the perceptions of the customers on the performance of the SBI and ICICI Bank.

\section{PERIOD OF THE STUDY}

The primary data has been collected from the customers of SBI and ICICI Bank for the year 2019-20.

\section{TOOLS OF ANALYSIS}

Data collected from the various sources have been analyzed with the help of appropriate simple and relevant mathematical and statistical tools. Some important tools that are deployed for the present study are percentages, Chi-Square test and the like.

\section{GENDER CATEGORIES OF THE RESPONDENT CUSTOMERS}

Sample respondent customers of SBI and ICICI Bank have been classified into male and female categories. The Gender-wise sample respondent customers of SBI and ICICI Bank are presented in table 1: 
International Journal of Social Science and Economic Research

ISSN: 2455-8834

Volume:05, Issue:09 "September 2020"

Table: 1: Gender-wise distribution of sample respondent customers of SBI and ICICI Bank

\begin{tabular}{|c|c|c|}
\hline Gender & SBI & ICICI Bank \\
\hline Male & 81 & 96 \\
& $(67.50)$ & $(80.00)$ \\
\hline Female & 39 & 24 \\
& $(32.50)$ & $\mathbf{1 2 0}$ \\
\hline Total & $\mathbf{1 2 0}$ & $\mathbf{( 1 0 0 )}$ \\
\hline \multicolumn{3}{|c|}{$\chi^{\mathbf{2}=\mathbf{4 . 8 4 2 6}^{*}}$} \\
\hline
\end{tabular}

Source: Field Survey

Note: * Significant at $5 \%$ level

It is observed from the table 1 that the sample respondent customers of SBI and ICICI Bank have been distributed as male and female categories. Majority of the respondent customers i.e., 81 out of 120 (67.50 per cent) of SBI were males, followed by 39 out of 120 (32.50 per cent) respondent customers belonging to female category. Similarly majority of the respondent customers i.e., 96 out of 120 ( 80.00 per cent) of ICICI Bank were males, followed by 24 out of 120 (20.00 per cent) respondent customers belonging to female category.

The calculated value of $\chi 2$-test statistic (4.8426) is much higher than its critical value (3.841). Hence, the null hypothesis may be rejected at $5 \%$ level of significance. It can be inferred that there is a significant association between the genders of sample respondent customers of SBI and ICICI Bank.

From the foregoing analysis one can infer that 96 out of 120 respondents of ICICI Bank and 81 out 120 of SBI belonged to male category whereas 39 out of 120 respondents (32.50 per cent) of SBI and 24 out of 120 respondents (20.00 per cent) of ICICI Bank were female respondents. The number of male respondent customers was significantly higher than the number of female respondent customers in both the banks.

\section{EDUCATIONAL QUALIFICATIONS OF THE RESPONDENT CUSTOMERS}

The sample respondent customers of SBI and ICICI Bank are classified according to their educational qualification. The details pertaining to Educational Qualifications of sample respondent customers of SBI and ICICI Bank are presented in table 2: 
International Journal of Social Science and Economic Research

ISSN: 2455-8834

Volume:05, Issue:09 "September 2020"

Table 2: Distribution of sample respondent customers of SBI and ICICI Bank over their educational qualifications

\begin{tabular}{|c|c|c|}
\hline Educational Qualifications & SBI & ICICI Bank \\
\hline Illiterate & 08 & 04 \\
& $(6.67)$ & $(3.33)$ \\
\hline \multirow{2}{*}{ Primary } & 12 & 09 \\
& $(10.00)$ & $(7.50)$ \\
\hline \multirow{2}{*}{ SSC } & 15 & 13 \\
& $(12.50)$ & $(10.83)$ \\
\hline UG & 51 & 31 \\
& $(42.50)$ & $(25.83)$ \\
\hline \multirow{2}{*}{ PG } & 20 & 37 \\
& $(16.67)$ & $(30.83)$ \\
\hline \multirow{2}{*}{ Professional } & 14 & 26 \\
& $(11.66)$ & $(21.67)$ \\
\hline \multirow{2}{*}{ Total } & $\mathbf{1 2 0}$ & $\mathbf{1 2 0}$ \\
\hline & $\mathbf{( 1 0 0 )}$ & \\
\hline & $\boldsymbol{2} \mathbf{2}=\mathbf{1 5 . 4 5 3}$ & \\
\hline
\end{tabular}

Source: Field Survey

Note: ${ }^{@}$ Not significant

Table 2 shows the distribution of sample respondent customers of SBI and ICICI Bank over their educational levels. It is understood from the table above that majority of the respondent customers of SBI ( 42.50 per cent) possess undergraduate degrees, followed by 20 respondents of SBI (16.67 per cent) having PG qualification, 15 respondents (12.50 per cent) having SSC, 14 respondents (11.66 per cent) having professional qualifications, 12 respondents (10.00 per cent) having primary education and 08 respondents ( 6.67 per cent) are illiterates. Whereas in the ICICI Bank, majority of the sample respondents ( 30.83 per cent) have PG degrees, followed by 31 respondents (25.83 per cent) having UG degrees, 26 respondents (21.67 per cent) having professional qualifications, 13 respondents (10.83 per cent) having SSC, 9 respondent (7.50 per cent) customers having Primary education and four respondent customers (3.33 per cent) are illiterates.

The calculated value of $\chi 2$-test statistic (15.453) is much higher than its critical value (11.070). Hence, the null hypothesis may be rejected at 5\% level of significance. It can be inferred that there is a significant association between the educational qualifications of sample respondent customers of SBI and ICICI Bank. 
From the foregoing analysis one can infer that majority of the respondent customers of SBI (42.50 per cent) possess undergraduate degrees whereas in the ICICI Bank majority of the respondent customers (30.83 per cent) have PG degrees. Thus, it can be inferred that the SBI could attract more graduates whereas the ICICI Bank could attract more PG graduates.

\section{MARITAL STATUS OF THE RESPONDENT CUSTOMERS}

The sample respondent customers of SBI and ICICI Banks are classified into married and unmarried categories. Statistical details pertaining to Marital Status of sample respondent customers of SBI and ICICI Bank are presented in table 3:

Table 3: Distribution of sample respondent customers of SBI and ICICI Bank over their marital status

\begin{tabular}{|c|c|c|}
\hline Marital Status & SBI & ICICI Bank \\
\hline Married & $\begin{array}{c}92 \\
(76.67)\end{array}$ & $\begin{array}{c}73 \\
(60.83)\end{array}$ \\
\hline Un- Married & $\begin{array}{c}28 \\
(23.33)\end{array}$ & $\begin{array}{c}47 \\
(39.17)\end{array}$ \\
\hline Total & $\begin{array}{c}120 \\
(100)\end{array}$ & $\begin{array}{c}120 \\
(100)\end{array}$ \\
\hline \multicolumn{3}{|c|}{$\chi 2=7.0012 * *$} \\
\hline
\end{tabular}

Source: Field Survey

Note: ** Significant at $1 \%$ level

Table 3 presents the distribution of sample respondent customers of SBI and ICICI Bank over married and unmarried categories. 92 out of 120 respondent customers (76.67 per cent) of SBI belong to married category and 28 out of 120 (23.33 per cent) are under unmarried category. Similarly 73 out of 120 (60.83 per cent) respondent customers of ICICI Bank are belong to married category and 47 out of 120 (39.17 per cent) belong to unmarried category.

The calculated value of $\chi 2$-test statistic (7.0012) is much higher than its critical value (6.635). Hence, the null hypothesis may be rejected at $1 \%$ level of significance. It can be inferred that there is a significant association between the marital status of sample respondent customers of SBI and ICICI Bank.

The inference that one can draw for the analysis above is that the proportion of married customers category in both the banks was much higher than the proportion of unmarried customers category. The proportion of married customers (76.67 per cent) to unmarried 
International Journal of Social Science and Economic Research

ISSN: 2455-8834

Volume:05, Issue:09 "September 2020"

customers in SBI was more than the proportion of married customers (60.83 per cent) to unmarried customers category in ICICI Bank. This indicates that ICICI Bank could attract more unmarried people than married.

\section{DURATION OF USING E-BANKING SERVICES}

The present scenario usage of ATMs, internet banking and mobile banking is measured in terms of the length of the period the respondents are using a particular service. For this purpose, time is divided into four subheads i.e., less than 6 months, 6 months to 1 year, 1 to 2 years and more than 2 years. The period of using e-banking services provided by the SBI \& ICICI Bank are presented in table 4:

Table 4: Period of using e-banking services provided by the SBI \& ICICI Bank

\begin{tabular}{|c|c|c|}
\hline Period & SBI & ICICI Bank \\
\hline Less than 6 months & $\begin{array}{c}11 \\
(13.20)\end{array}$ & $\begin{array}{c}15 \\
(12.50)\end{array}$ \\
\hline 6 months to 1 year & $\begin{array}{c}20 \\
(16.67)\end{array}$ & $\begin{array}{c}18 \\
(15.00)\end{array}$ \\
\hline 1 to 2 years & $\begin{array}{c}38 \\
(31.67)\end{array}$ & $\begin{array}{c}40 \\
(33.33)\end{array}$ \\
\hline More than 2 years & $\begin{array}{c}51 \\
(42.50)\end{array}$ & $\begin{array}{c}47 \\
(39.17)\end{array}$ \\
\hline Total & $\begin{array}{c}120 \\
(100)\end{array}$ & $\begin{array}{c}120 \\
(100)\end{array}$ \\
\hline \multicolumn{3}{|c|}{$\chi^{2}=0.935^{@}$} \\
\hline
\end{tabular}

\section{Source: Field Survey \\ Note: ${ }^{\circledR}$ Not significant}

Table 4 reveals that the response of the bank customers of SBI \& ICICI Bank by Period of time using e-banking services. Out of 120 State Bank of India sample respondent customers 42.50 per cent that they are using from more than 2 years, 31.67 per cent are using from 1 to 2 years, 16.67 per cent are using 6 months to 1 year and only 13.20 per cent are using from less than 6 months. Whereas in the ICICI Bank sample respondent customers 39.17 per cent that they are using from more than 2 years, 33.33 per cent are using from 1 to 2 years, 15.00 per cent are using 6 months to 1 year and only 12.50 per cent are using from less than 6 months.

Since the calculated value of $\chi 2$-test statistic (0.935) is much less than its critical value (7.815), the null hypothesis may be accepted at $5 \%$ level of significance. It can be inferred that there is no 
International Journal of Social Science and Economic Research

ISSN: 2455-8834

Volume:05, Issue:09 "September 2020"

significant association between time period usage of e-banking services provided by the SBI and ICICI Bank.

From the foregoing analysis one can infer that majority of the respondent customers of SBI (42.50 per cent) that they are using from more than 2 years whereas in the ICICI Bank was 39.17 per cent are using from more than 2 years. Hence it can be concluded that the majority of both SBI \& ICICI Bank sample respondent customers are using e-banking services from more than 2 years.

\section{AWARENESS OF VARIOUS E-BANKING SERVICES AMONG BANK CUSTOMERS}

Awareness of various e-banking services among sample respondent customers of SBI and ICICI Bank are presented in table 5:

Table 5: Distribution of sample respondent customers of SBI and ICICI Bank over the awareness of various e-banking services

\begin{tabular}{|c|c|c|}
\hline Mode of Transactions & SBI & ICICI Bank \\
\hline Personal Visit & 33 & 29 \\
& $(27.50)$ & $(24.17)$ \\
\hline \multirow{2}{*}{ Through ATM } & 38 & 35 \\
& $(31.67)$ & $(29.17)$ \\
\hline \multirow{2}{*}{ Phone Banking } & 16 & 21 \\
& $(13.33)$ & $(17.50)$ \\
\hline \multirow{2}{*}{ Home Banking } & 09 & 13 \\
& $(7.50)$ & $(10.83)$ \\
\hline \multirow{2}{*}{ Net Banking } & 24 & 22 \\
& $(20.00)$ & $\mathbf{1 2 0}$ \\
\hline \multirow{2}{*}{ Total } & $\mathbf{1 2 0}$ & $\mathbf{( 1 0 0 )}$ \\
\hline
\end{tabular}

Source: Field Survey

Note: * Significant at $5 \%$ level

Table 5 depicts the Distribution of sample respondent customers of SBI and ICICI Bank over the awareness of various e-banking services. It is understood from the table above that majority of the respondent customers of SBI (31.67 per cent) are operating their bank accounts through ATMs followed by 33 respondent customers of SBI said that they personally visit their bank branches to operate their banking transactions, 24 respondent customers have responded that the mode of operation they opted for operating their accounts is net banking, 16 respondent 


\section{International Journal of Social Science and Economic Research}

ISSN: $2455-8834$

Volume:05, Issue:09 "September 2020"

customers have opted phone banking operations and 9 respondent customers have opted home banking for operating their accounts with their respective banks.

Similarly 35 respondent customers of ICICI Bank have responded that they did their banking transactions through their ATMs followed by 29 respondent customers of ICICI Bank transacting with their bank only through their personal visit, 22 respondent customers of ICICI Bank could transact their bank by means of net banking, 21 respondent customers of ICICI Bank transacting with their bank over phone and 13 respondent customers of ICICI Bank just by sitting at their home banking.

The calculated value of $\chi 2$-test statistic (1.871) is much less than its critical value (9.488). Hence, the null hypothesis may be accepted at $5 \%$ level of significance. It can be inferred that there is no significant association between awareness of various e-banking services among sample respondent customers of SBI and ICICI Bank.

Based on the analysis given above, one can infer that majority of the respondent customers of SBI (31.67 per cent) and ICICI Bank (29.17 per cent) responded that they performed their banking operations with their respective banks by means of ATMs. Majority of the respondent customers of those who said that they used ATM cards for operating their bank accounts with their respective banks were representing SBI.

\section{SUGGESTIONS}

$>$ Banks can influence their customer to use internet banking by making their customer aware about the utility of the service and when customer find it more useful then they defiantly go with internet banking. Proper marketing communication through proper marketing campaigns would increase consumer awareness and better acceptance of Internet banking.

$>$ The factor consumer security concerns had a negative influence on internet banking use. Banks should try to mitigate concerns of their customers in terms of internet banking technology to increase customer acceptance. Banks should also take measure the trust and privacy of its internet banking infrastructure and procedures.

$>$ The thumb impression is used as a PIN code or Password for Internet Banking to avoid hacker's money theft in technological banking.

$>$ The software application for mobile banking is not suitable for all mobile phones. Due to tremendous development in the latest technologies in the mobile phones. Customers have various models of mobiles. So satisfy their customers banker has to take proper steps in having suitable software for all types of mobile phones. 


\section{International Journal of Social Science and Economic Research}

ISSN: $2455-8834$

Volume:05, Issue:09 "September 2020"

Charges, exchange rates, interest rates for deposits and for taking demand draft are to be send to the customers periodically through SMS alters. It helps the customer to make interest to deposit money and take DD if necessary without having many quires while at the working time.

\section{CONCLUSION}

The last two decade has seen many constructive developments in the Indian Banking Sector. Now-a-days e-banking is the popular technology used by banks. E-banking is the outcome of technological innovations and competition. In fact, banks have been using electronic and telecommunication networks for delivering a wide range of value added products and services. As the popularity of e-banking is increasing and banks are adopting the latest technology, they are prone towards cyber crimes and greater is the potential for reputational risks also, therefore, there is a need to have sound security controls and strong cyber laws in India. The future of Internet banking lies in offering personalized Internet based services that are not only valued by their customers but are also unique to them. This would help distinguish themselves in the crowd. This would also help them evolve continuously to meet customers' needs, capitalizing on new technology to build stronger customer relationship.

\section{REFERENCES}

1. Uppal R. K., "Customer Perception of E-Banking Services of Indian Banks: Some Survey Evidence", The ICFAI University Journal of Bank Management, Vol. VII, Issue I, February, 2008, pp.63-78.

2. Harikant, "Customer Perception towards Computerisation in Indian Banks - A Study of Selected Banks", Thavan IJREB, Vol. 1, No.2, Jan-Mar, 2002, pp.1-8.

3. Jayanthi. M. and Umarani. R., "Customer Perception and Satisfaction -towards Internet Banking Services“, Zenith International Journal of Multidisciplinary Research, Vol.2, Issue 8, August, 2012, pp.1-10.

4. Malika Rani, "Study on the Customer Perception Towards E-Banking in Ferozpur District", Zenith International Journal of Multidisciplinary Research, Vol.2, Issue 1, January, 2012, pp.108-118.

5. Pinki Insan and Sapna Kumari, “Customer's Perception towards Internet Banking: A Study of Sirsa City", IOSR Journal of Business and Management, 2015, pp 52-59. 
6. Krishnamoorthy, V. and R. Srinivasan, Internet Banking as a tool for Customer Relationship Management - A Study on Customer Perspective, Indian Journal of Research, Volume 2, Issue 2, 2013, pp 187-190.

7. Safeena, R., Abdullah and H. Date, Customer's Perspective on E-Business Value: A Case Study on Internet Banking, Journal of Internet Banking and Commerce, Volume 15, No. 1, 2010, pp 2-8.

8. Thanga Glara. K. \& Eugine Franco. C., "A Comparative Study on Satisfaction of Customers of Public Sector and Private Sector Banks towards E-Banking In Tirunelveli District", International Journal of Research - Granthaalayah, Vol.5, Iss.5, May, 2017, Pp.53-62. 